\title{
Fermilab
}

Managed by Fermi Research Alliance, LLC for the U.S. Department of Energy Office of Science

\section{Partnerships \& Technology Transfer: Accessing National Laboratory Resources}

Cherri J Schmidt \& Aaron G Sauers 2018 Midwest Regional Workshop on ASTFP

5 December 2018

This manuscript has been authored by Fermi Research Alliance, LLC under Contract No. DE-AC02-07CH11359 with the U.S. Department of Energy, Office of Science, Office of High Energy Physics. 
Partnerships \& Technology Transfer: Accessing National Laboratory Resources

- The National Lab System

- Fermilab's Technology Strengths

- Fermilab as an Engine of Innovation

- Partnering Mechanisms

- Licensing Opportunities

- OPTT Team 


\section{The National Laboratory System}

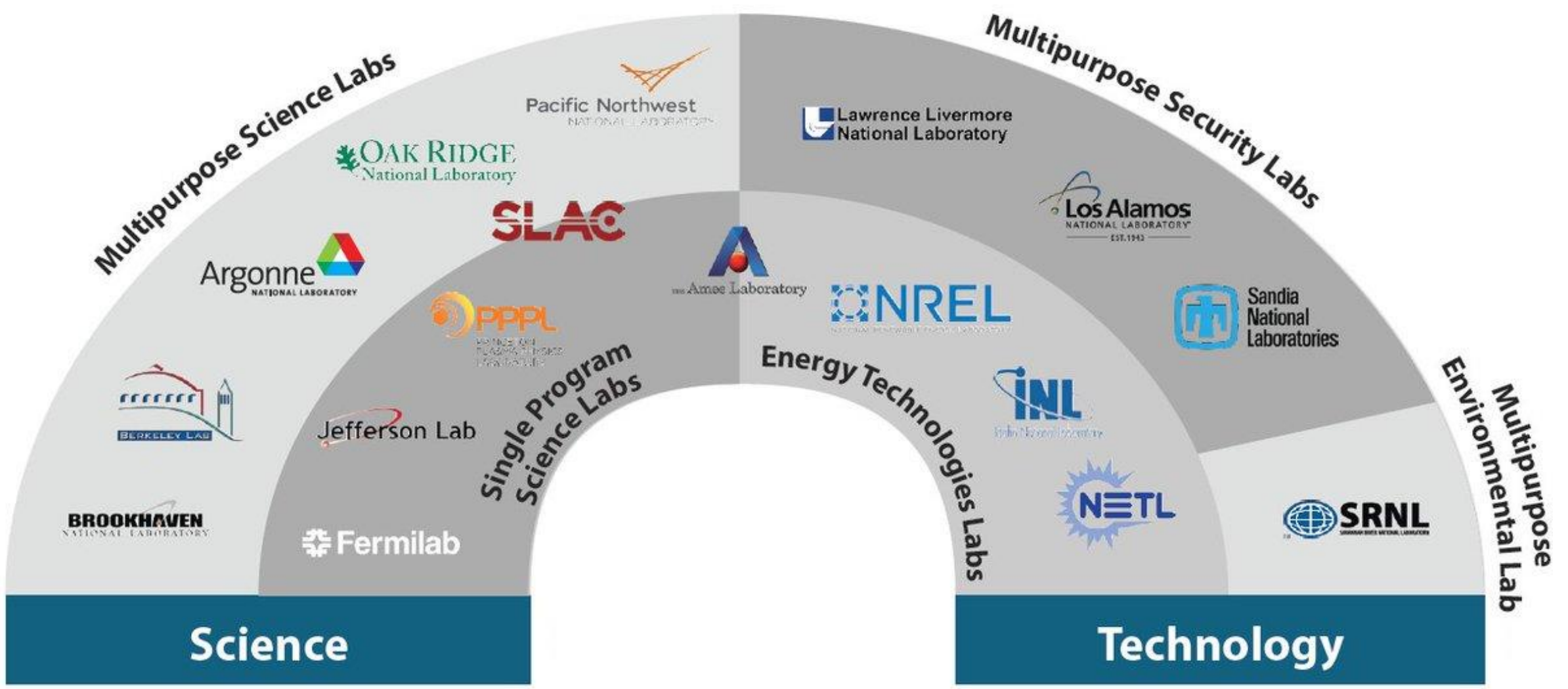




\section{Fermilab's Technology Strengths}

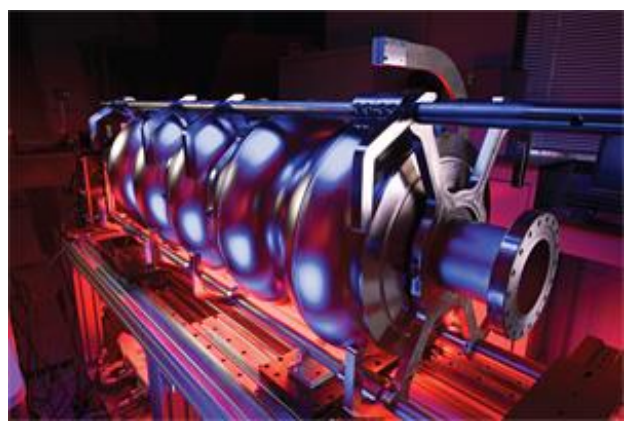

\section{Accelerator Technology}

Fermilab is the U.S. accelerator laboratory, dedicated to developing particle accelerators for physics research. This technology also has many applications outside of physics, including medical applications like PET scans and commercial applications like curing rubber tires or shrinkwrapping products. Through the Illinois Accelerator Research Center (IARC), Fermilab partners with industry and universities to help create accelerator-based products, applications, companies and jobs

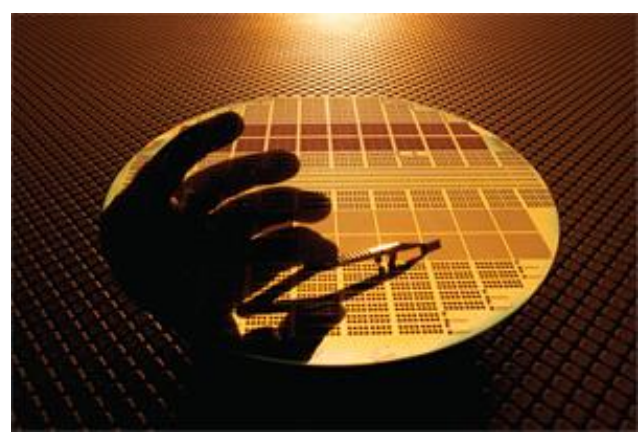

\section{Detector Technology}

Accelerators can collide particles together, but scientists need detectors to reveal what happens when they do. Fermilab has been at the forefront of detector technology for decades, working most recently on the massive CMS detector at the Large Hadron Collider in Switzerland and the next generation of neutrino detectors for experiments in the U.S. The technologies developed for these physics experiments can be applied to fields as diverse as the financial industry and medical diagnostics.

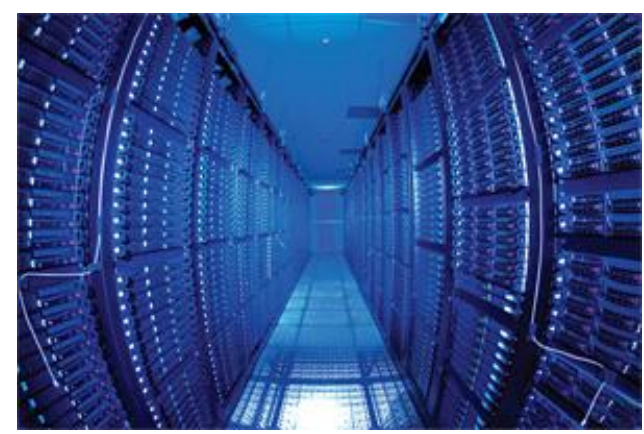

\section{Computing Technology}

Particle physics experiments produce an enormous amount of data. It takes an extraordinary amount of computing power to sift through that data and find the one signal in a billion that could tell us more about our universe. Fermilab's computing innovations have led to multiple applications, driven by our need to process massive amounts of information, store it and transmit it effectively. 


\section{Fermilab as an engine of innovation}

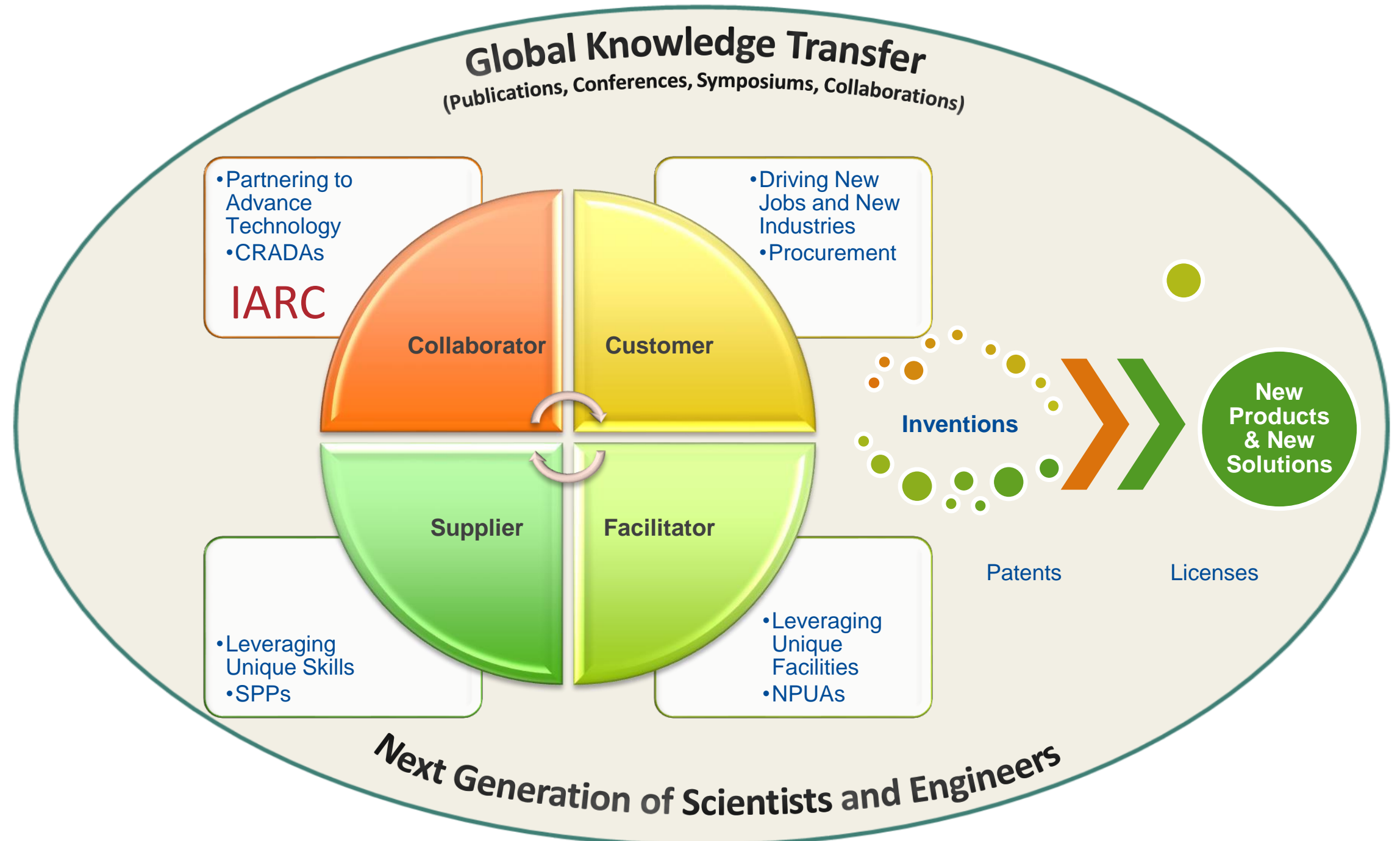




\section{User Facilities}

- Federally sponsored research facility available for external use to advance scientific or technical knowledge

- Open to all without regard to nationality or institutional affiliation

- Allocation of facility resources determined by merit review

- User fees are not charged for non-proprietary work; results must be published

- Full cost recovery (private funds) required for proprietary work (IP and data)

- Facility provides resources sufficient to conduct work safely and efficiently

- Facility supports a formal user organization

- Facility capability does not compete with an available private sector capability 


\section{User Facilities in Illinois}

- Argonne is home to five national user facilities with 5000 users

- Advanced Photon Source (APS)

- Argonne Leadership Computing Facility

- Argonne Tandem Linear Accelerator System

- ARM Southern Great Plains

- Center for Nanoscale Materials

- Fermilab is home to one very large national user facility with 2000 users

- 6800 acre site

- $16 \mathrm{~km}$ of accelerators \& beam lines

- Seven accelerators

- Two primary proton beams

- Secondary beams of pions, kaons, muons and neutrinos
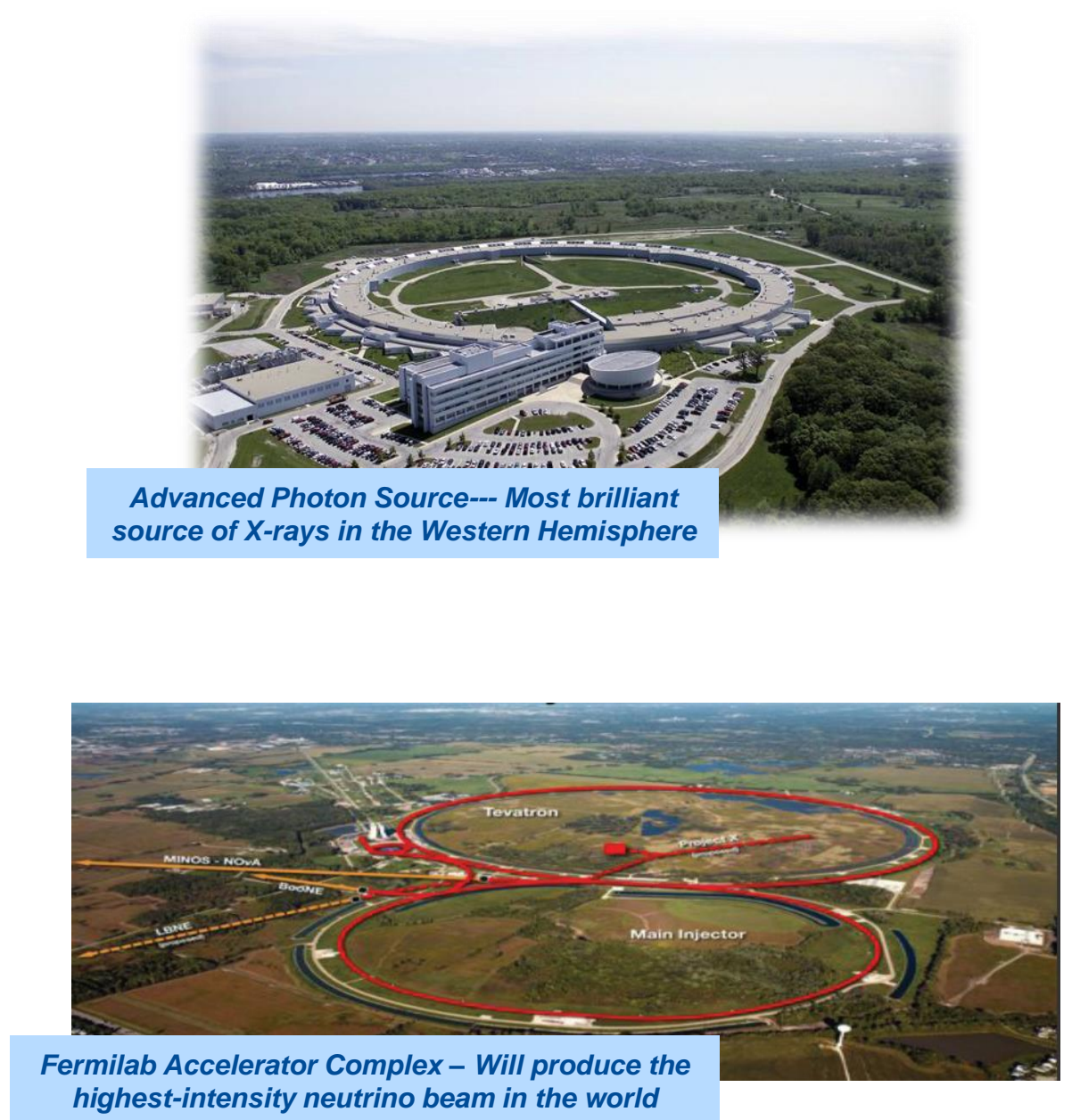


\section{Partnering Mechanisms}

\section{Non-Proprietary User Agreement (NPUA)}

Researchers can access Fermilab's unique Scientific User Facilities without paying a user fee.

$\checkmark \quad$ Users commit to publishing research results in the open literature

$\checkmark$ Users retain the right to elect title to their own inventions

$\checkmark$ Department of Energy retains unlimited rights in generated data

Users are responsible for their own experimental costs.

Fermilab provides users with resources sufficient to conduct work safely and efficiently.

Users may access additional services by establishing User Accounts.

\section{Proprietary User Agreement}

Fermilab does not currently utilize the Proprietary User Agreement, although it is available at other DOE User Facilities. Under a Proprietary User Agreement:

- Users pay full cost for use of specialized laboratory equipment

- Users retain as proprietary technical data generated (with limited exceptions)

- Users retain rights to any new inventions 


\section{Partnering Mechanisms}

\section{Strategic Partnership Projects (SPP) Agreements}

Formerly referred to as Work for Others (WFO), SPPs provide an excellent way for companies, universities, and other institutions to access the unique facilities, technologies, and expertise available at Fermilab on a project-specific basis.

Under an SPP agreement, a Partner can pay full cost recovery for unique laboratory services and receive these benefits:

- Retain right to elect title to Subject Inventions

- Protect generated data as proprietary

- Opt for a limited government R\&D license (certain restrictions apply)
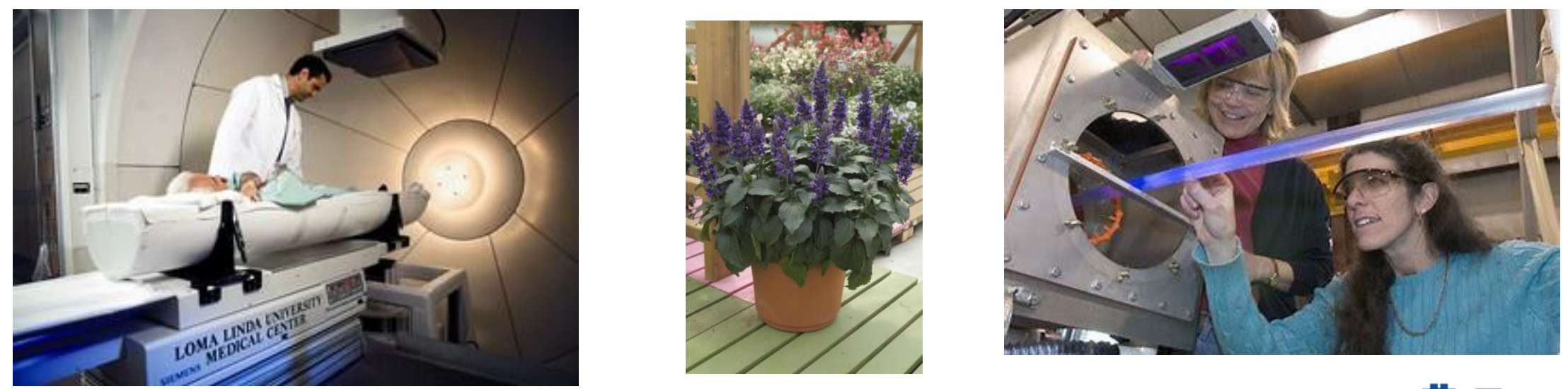


\section{Partnering Mechanisms}

\section{Cooperative Research and Development Agreement (CRADA)}

CRADAs provide a way for DOE laboratories to engage in collaborative research and development agreements with both public and private entities, for the mutual benefit of both parties. Under a CRADA:

- $\quad$ The Lab and the Partner may share costs or the Partner may pay $100 \%$ of the costs

- The Lab and the Partner may elect title to their own inventions, share joint inventions

- Partner has the right to negotiate exclusive license to Lab inventions

Carbon Nanotube Cathode

RadiaBeam Technologies

Northern Illinois University

Fermilab
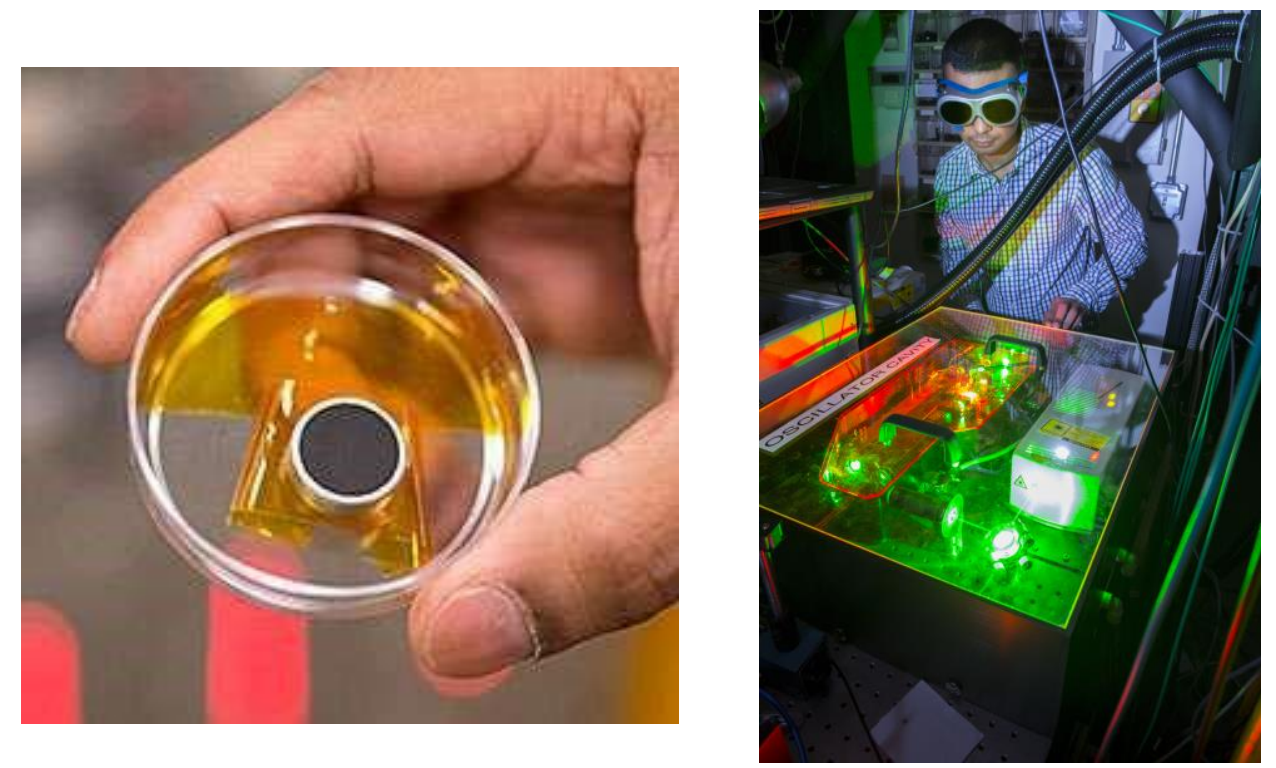


\section{A Few Rules of Engagement}

- Projects need to be clearly defined and scheduled in advance

- Projects should be consistent with or complement the mission of the laboratory and the Department of Energy (DOE)

- Projects cannot conflict or interfere with regular ongoing programs at the laboratory

- Labs may not directly compete with the domestic private sector

- Labs may not take on work that creates a future "burden" for DOE

- The DOE and the labs do not provide product endorsements 


\section{Typical Process}

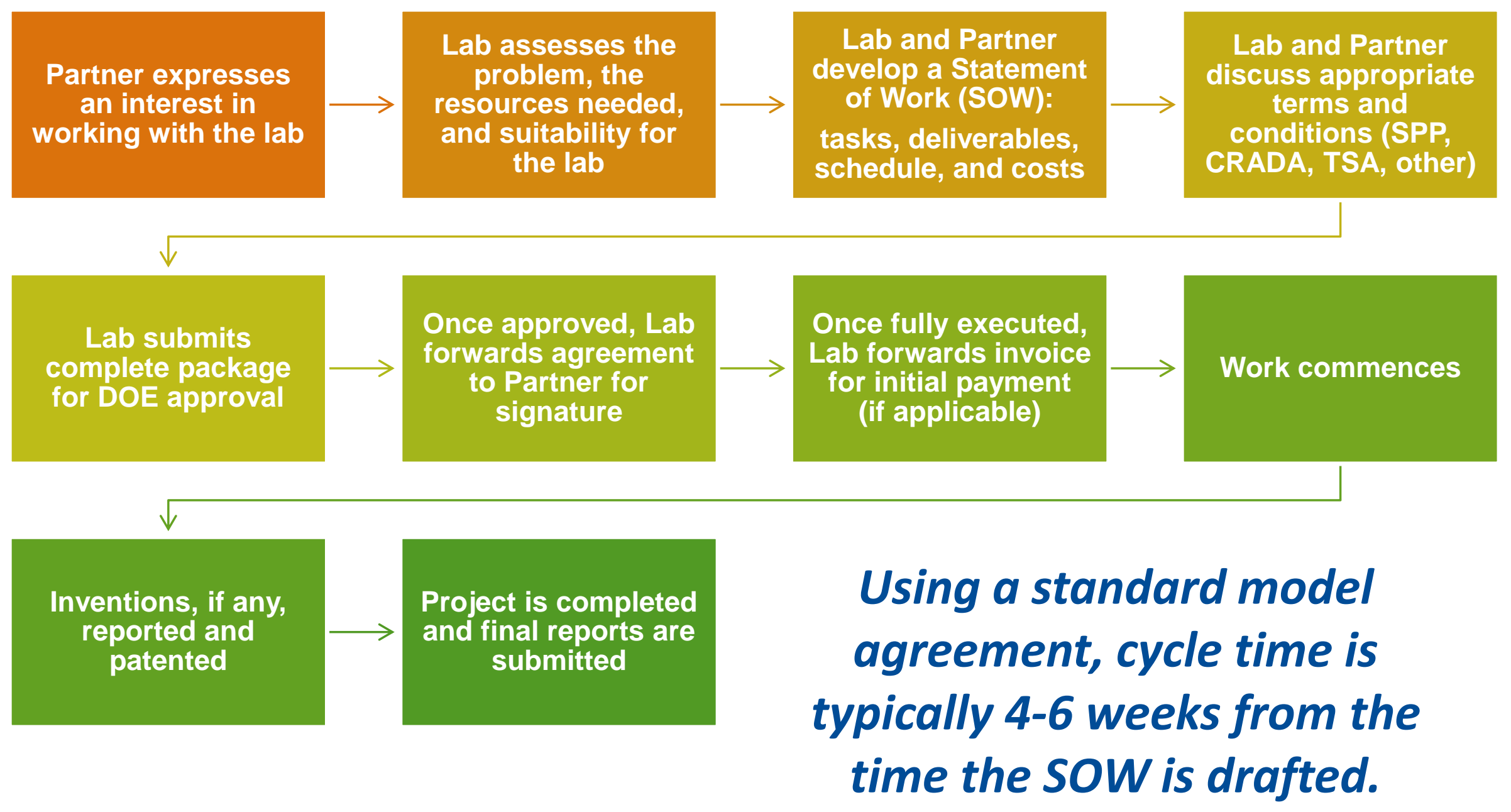




\section{Licensing Technologies}

- Fermilab holds a small number of patents and copyrights that are available for licensing to interested parties.

- Such licensing may be non-exclusive or exclusive depending on the interests of the laboratory and the licensing party.
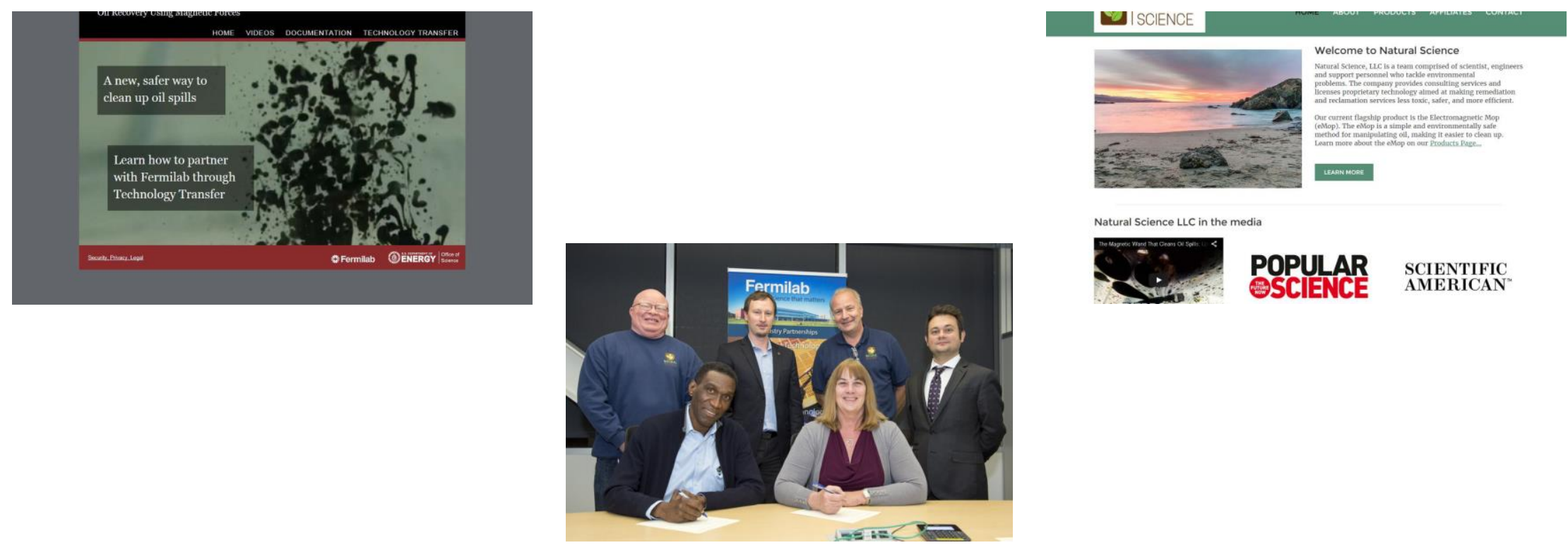

Natural Science LLC in the media

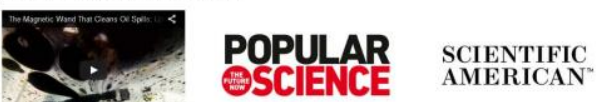




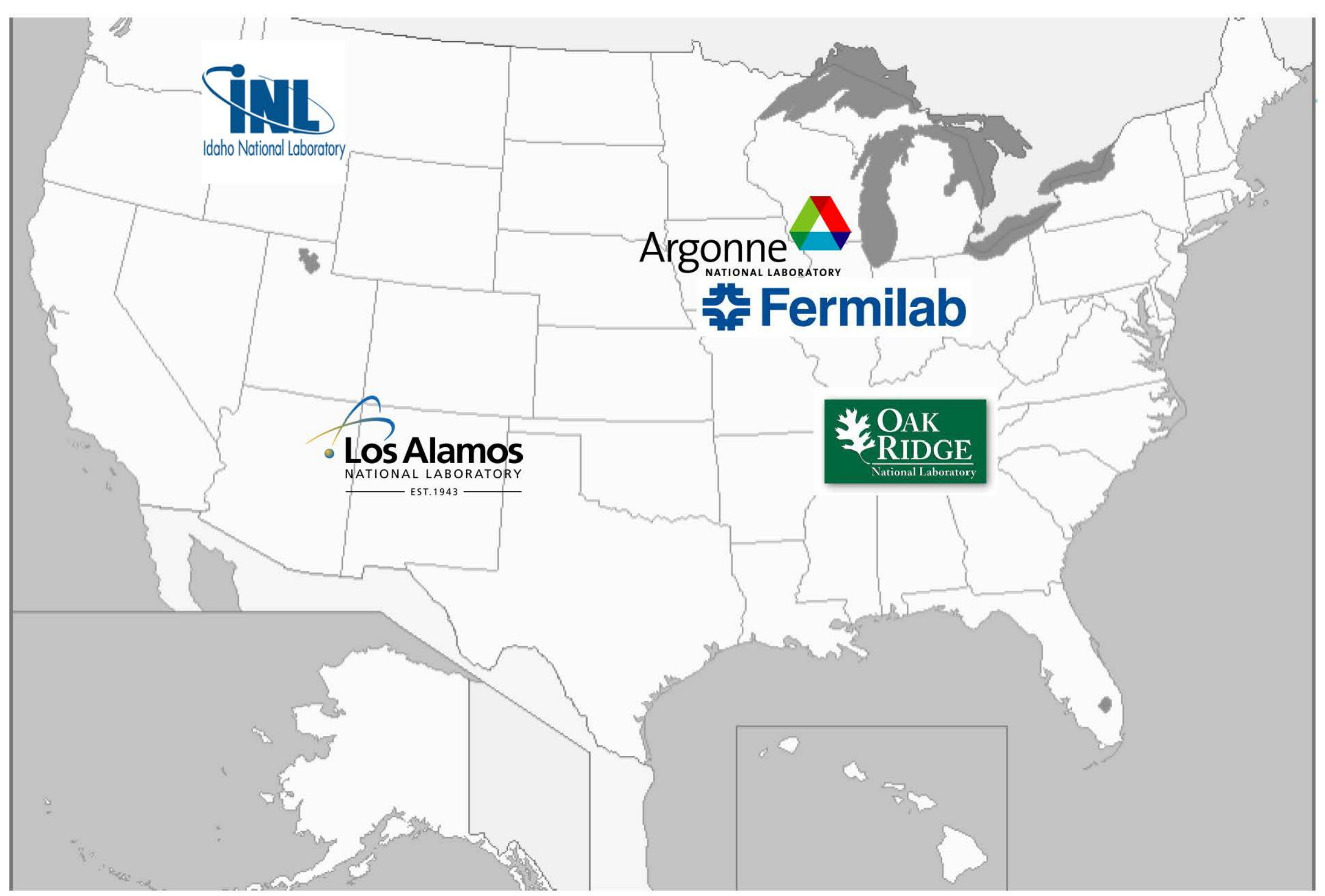




\section{Intellectual Property}

- Patents

- Methods

- software algorithms

- cavity treatment processes

- Apparatuses

- cavity couplers

- radiation detectors

- Copyrights

- Software

- MARS15

- Schematics

- Trademarks (rare)

- partnerships.fnal.gov

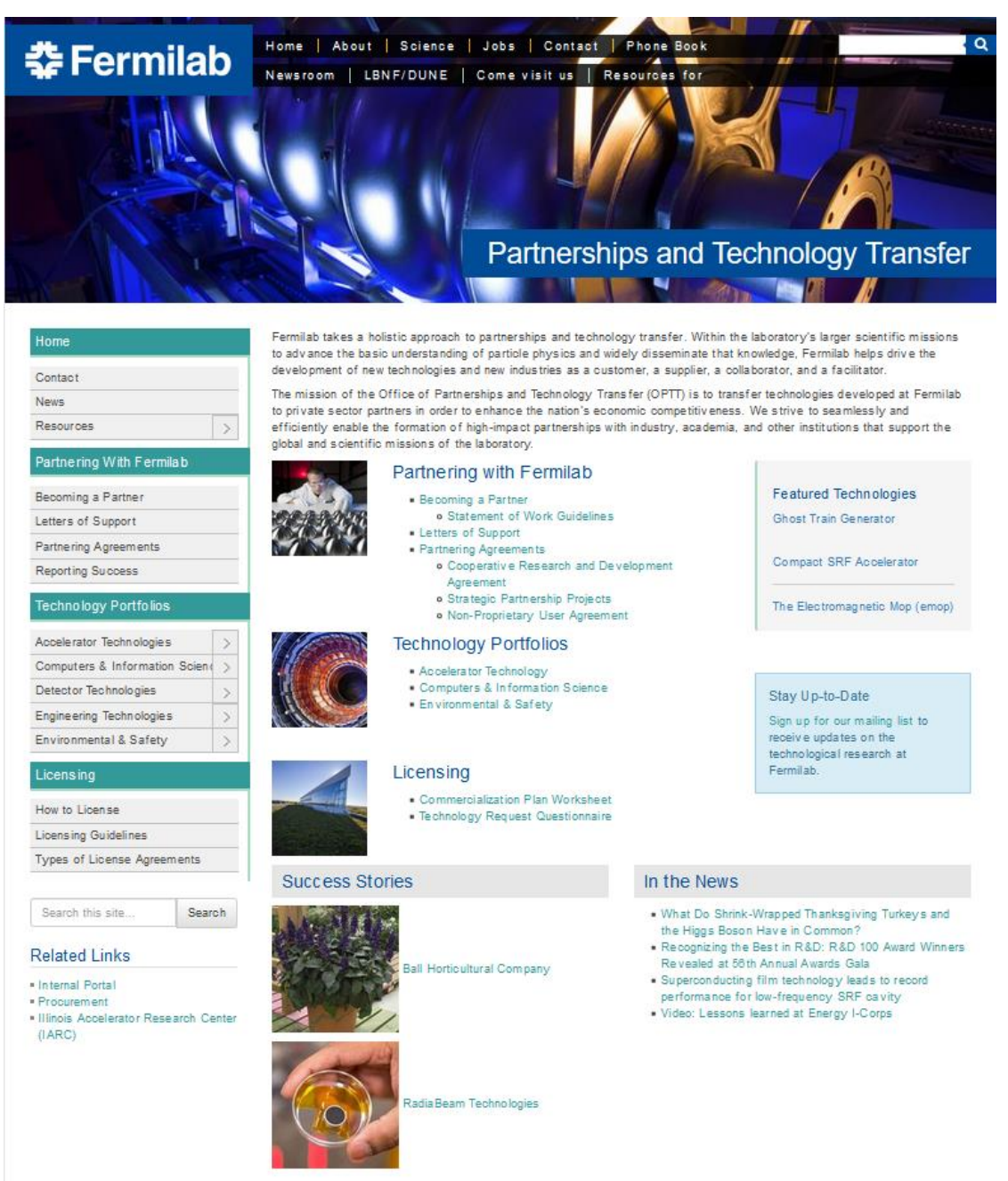

贲 Fermilab 


\section{Licensing}

- Terms: Typical of industrial licensing

- Exclusive, partially exclusive, non-exclusive, options

- Field of use and/or territory

- License Fee and/or royalties based on sales

- Diligence requirements

- Background and Subject inventions are available

- Government retains specific rights

- partnerships.fnal.gov

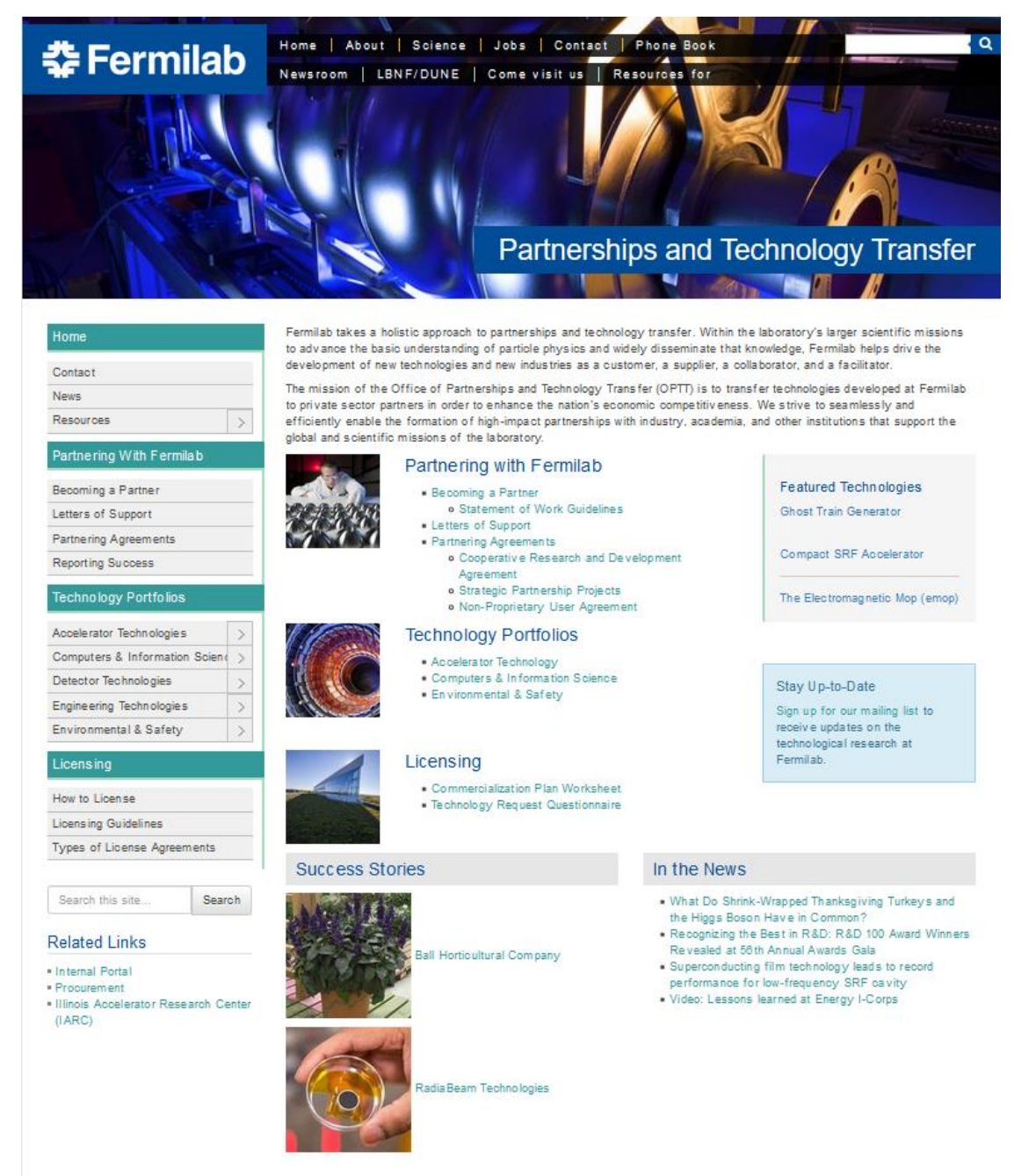




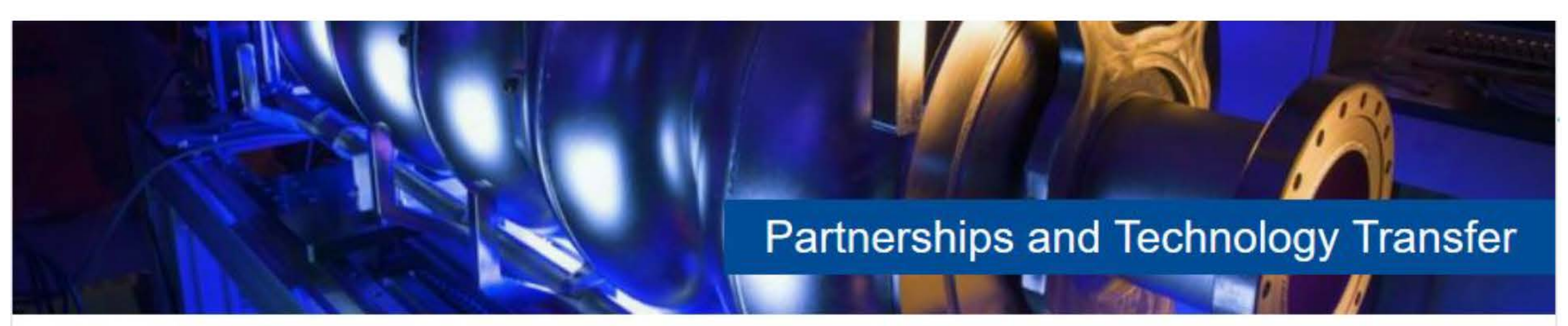

\section{Home}

\begin{tabular}{l|l|}
\hline Contact & \\
\hline News & $>$ \\
\hline Resources & \\
\hline
\end{tabular}

Partnering With Fermilab

Becoming a Partner

Letters of Support

Partnering Agreements

Reporting Success

Technology Portfolios

\begin{tabular}{|l|r|}
\hline Accelerator Technologies & $>$ \\
\hline Computers \& Information Scienc & $>$ \\
\hline Detector Technologies & $>$ \\
\hline Engineering Technologies & $>$ \\
\hline Environmental \& Safety & $>$ \\
\hline
\end{tabular}

Licensing

\section{Technology Portfolios}

Fermilab holds a number of patents and copyrights that are available for licensing to interested parties. Such licensing may be non-exclusive or exclusive depending on the interests of the laboratory and the licensing party. Here are just a few of Fermilab's newest technologies that are available for license:

Accelerator Technologies Computers \& Information Detector Technologies

Engineering Technologies
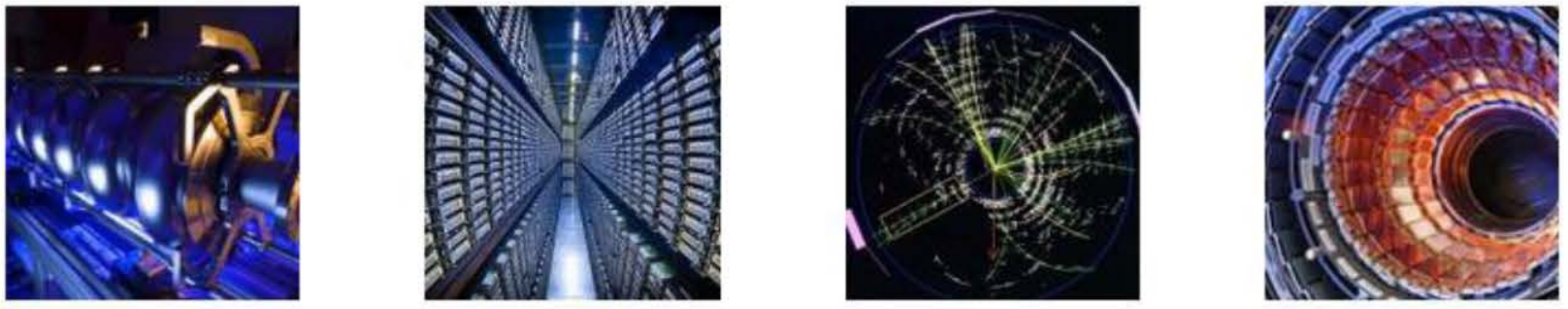

Environmental \& Safety

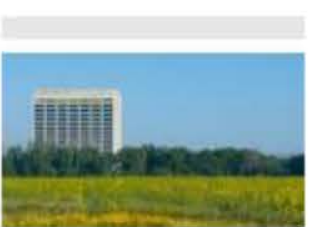




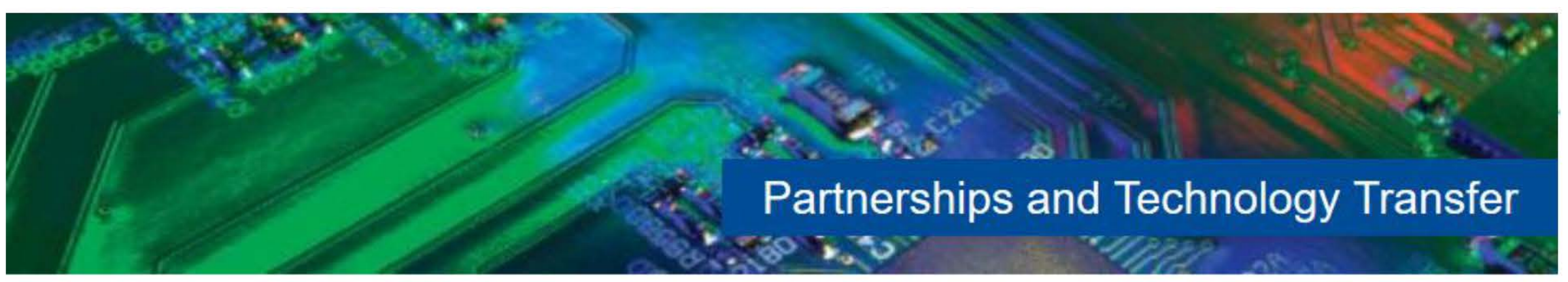

\section{Home}

\begin{tabular}{|c|c|}
\hline \multicolumn{2}{|l|}{ Contact } \\
\hline News & \\
\hline Resources & $>$ \\
\hline
\end{tabular}

Partnering With Fermilab

\section{Becoming a Partner}

Letters of Support

Reporting Success

Technology Portfolios

Accelerator Technologies

- Compact SRF Accelerator

- Pavement

- Magnetron

- 3D Additive Manufacturing with High Power Electron Gun

" Conduction Cooling

- Low Heat Leak Power Coupler
Partnering Agree ments

\section{Accelerator Technologies}

Fermilab is the U.S. accelerator laboratory, dedicated to developing particle accelerators for physics research. This technology also has many applications outside of physics, including medical applications like PET scans and commercial applications like curing rubber tires or shrinkwrapping products. Through the Illinois Accelerator Research Center (IARC), Fermilab partners with industry and universities to help create accelerator-based products, applications, companies and jobs.
Compact SRF Accele rator

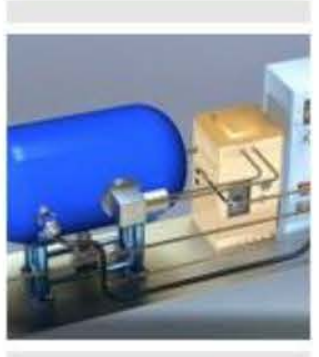

3D Additive Manufacturing

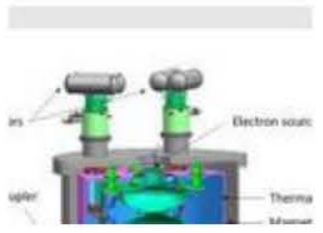

Pavement

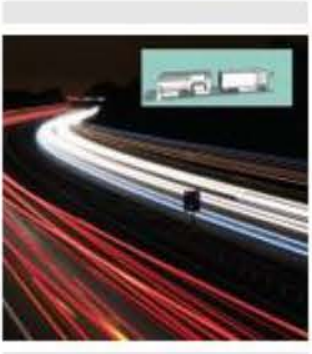

Conduction Cooling

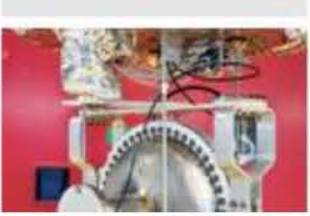

Magnetron

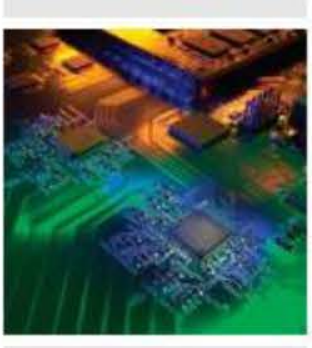

Low Heat Leak Coupler

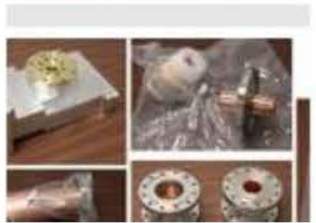

MARS15

sent MARS15 Applications
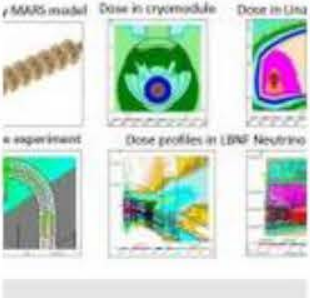

Fast Faraday Cup

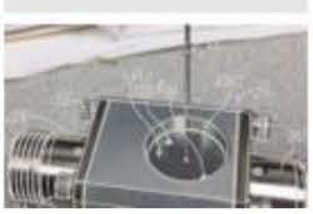




\section{Partnerships and Technology Transfer}

\begin{tabular}{l|l|}
\hline Home \\
\hline Contact \\
\hline News \\
\hline Resources \\
\hline Partnering With Fermilab \\
\hline Becoming a Partner \\
\hline Letters of Support \\
\hline Partnering Agreements \\
\hline Reporting Success \\
\hline Technology Portfolios \\
\hline Accelerator Technologies \\
\hline - Compact sRF Accelerator \\
\hline = Pave ment \\
= Magnetron \\
= 3D Additive Manufacturing with \\
\hline High Power Electron Gun \\
" Conduction Cooling \\
= Low Heat Leak Power Coupler \\
- Fast Faraday Cup \\
\hline Computers \& Information Scienc \\
\hline Detector Technoloaies \\
\hline
\end{tabular}

\section{Compact SRF Accelerator}

\section{Technology Summary}

Accelerators developed for science now are used broadly for in dustrial, medical, and security applications. Over 30,000 accelerators touch over $\$ 500 \mathrm{~B} / \mathrm{yr}$ in products producing a major impact on our e conomy, health, and well-being. In dustrial accelerators must be cost-effective, simple, versatile, efficient, and robust. Many industrial applications require high average beam power.

\section{The Invention}

Exploiting recent advances in Superconducting Radio Frequency (SRF) cavities and RF power sources as well as innovative solutions for the SRF gun and cathode system we have developed a de sign for a compact SRF high-average power electron linac. Capable of $>250 \mathrm{~kW}$ average power and continuous wave operation, this accelerator produces electron beam en ergies up to $10 \mathrm{MeV}$.

\section{Benefit}

Small and light enough to mount on mo bile platforms, Fermilab Compact SRF accelerators enable new in-situ environmental reme diation, in-situ crosslinking of mate rials, and security applications. More importantly, this accele rator will be the first of a new class of simple, turn-key SRF acceler ators.

\section{Applications and Industries}

- Industry

- Medicine

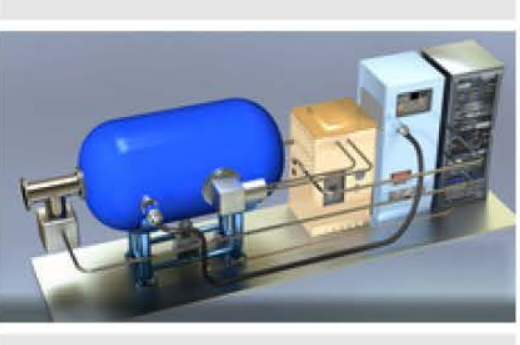

Invention Details

Patent Status: Multiple patents pending

Contact:
Aaron G Sauers, CLP
$630-840-4432$
as auers@fnal.gov
Fermilab, MS 312-PO Box 500
Batavia, IL 60510




\section{Partnerships and Technology Transfer}

\section{Home}

Contact

News

Resources

Partnering With Fermilab

\section{Becoming a Partner}

Letters of Support

Partnering Agreements

Reporting Success

\section{Technology Portfolios}

\begin{tabular}{|l|l|}
\hline Accelerator Technologies & $>$ \\
\hline Computers \& Information Science & $>$ \\
\hline Detector Technologies & $>$ \\
\hline Engineering Technologies & $>$ \\
\hline Environmental \& Safety & $>$ \\
\hline
\end{tabular}

\section{Licensing}

\section{How to License}

Licensing Guidelines

Types of License Agreements

\section{How to License}

\section{Technology Evaluation}

The first step in the licensing process is for you to identify technologies that interest you. Please see our Technology Portfolios to assist you. At any point if you have questions, contact our Licensing Executive, Aaron G. Sauers, CLP, 630-840-4432, asauers@fnal.gov. He will be available to work with you to manage the development, review and approval processes for your license.

\section{License Plan}

Fermilab requires a Commercialization Plan Worksheet from prospective licensees before licensing its intellectual property. The plan better enables Fermilab and the prospective licensee to determine the business fit between their interests. The type of license depends on the technology, the nature of the organization seeking a license, and the intended use. In addition, you may be required to complete a Technology Request Questionnaire.

\section{Term Sheet Negotiation}

Once we have reviewed and approved your plan to commercialize the technology, we will begin discussing licensing terms. You are encouraged to review the DOE Licensing Guide and sample License Agreements prior to beginning negotiations.

The OPTT office will review a term sheet based on your input in your Commercialization Plan and your business plan. Term sheets include financial terms (e.g up-front execution fee, patent cost reimbursement, minimum royalty payments and running royalty payments). View an example of a Term Sheet.

\section{License Execution}

Once we have agreed upon the license terms, we will draft an executable License Agreement for your review and signature. The license will normally become effective when all parties have signed the License Agreement and any execution fee has been received. 


\section{www.federallabs.org}

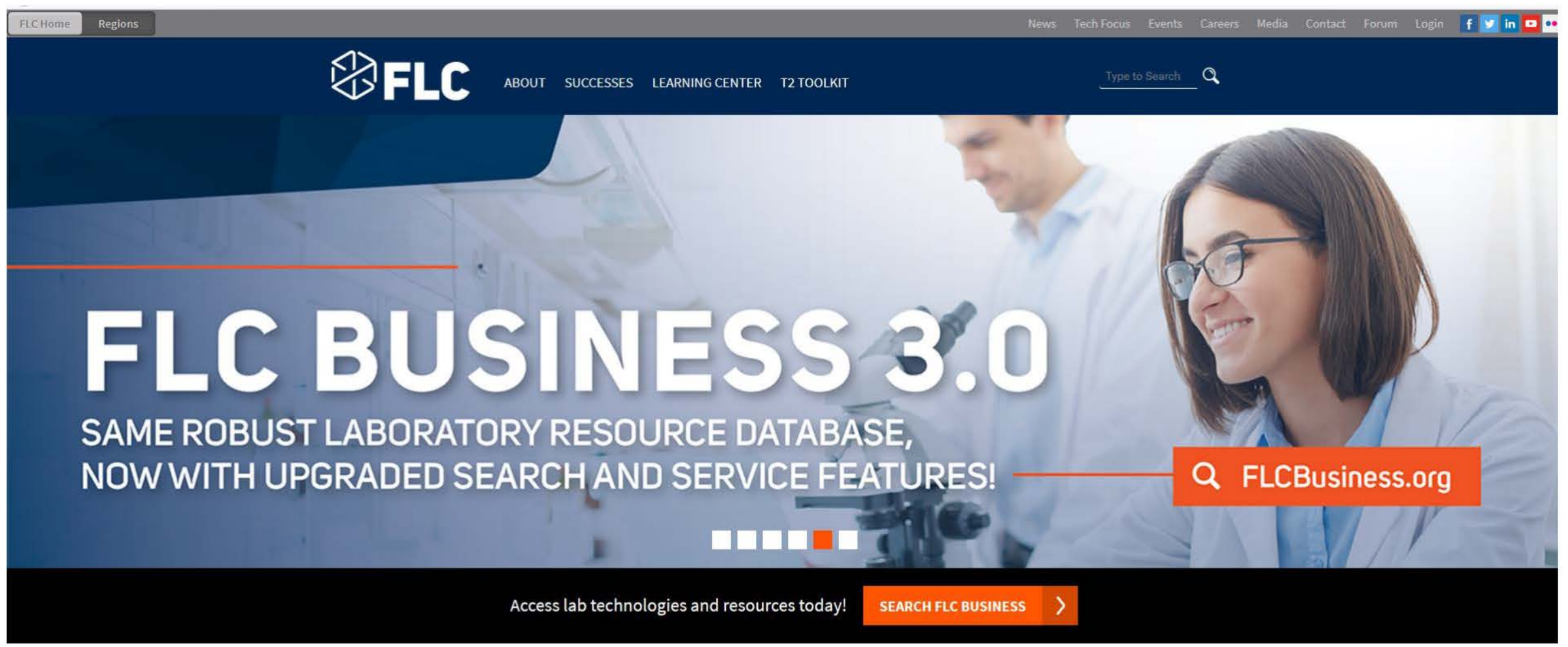




\section{www.fbo.gov}

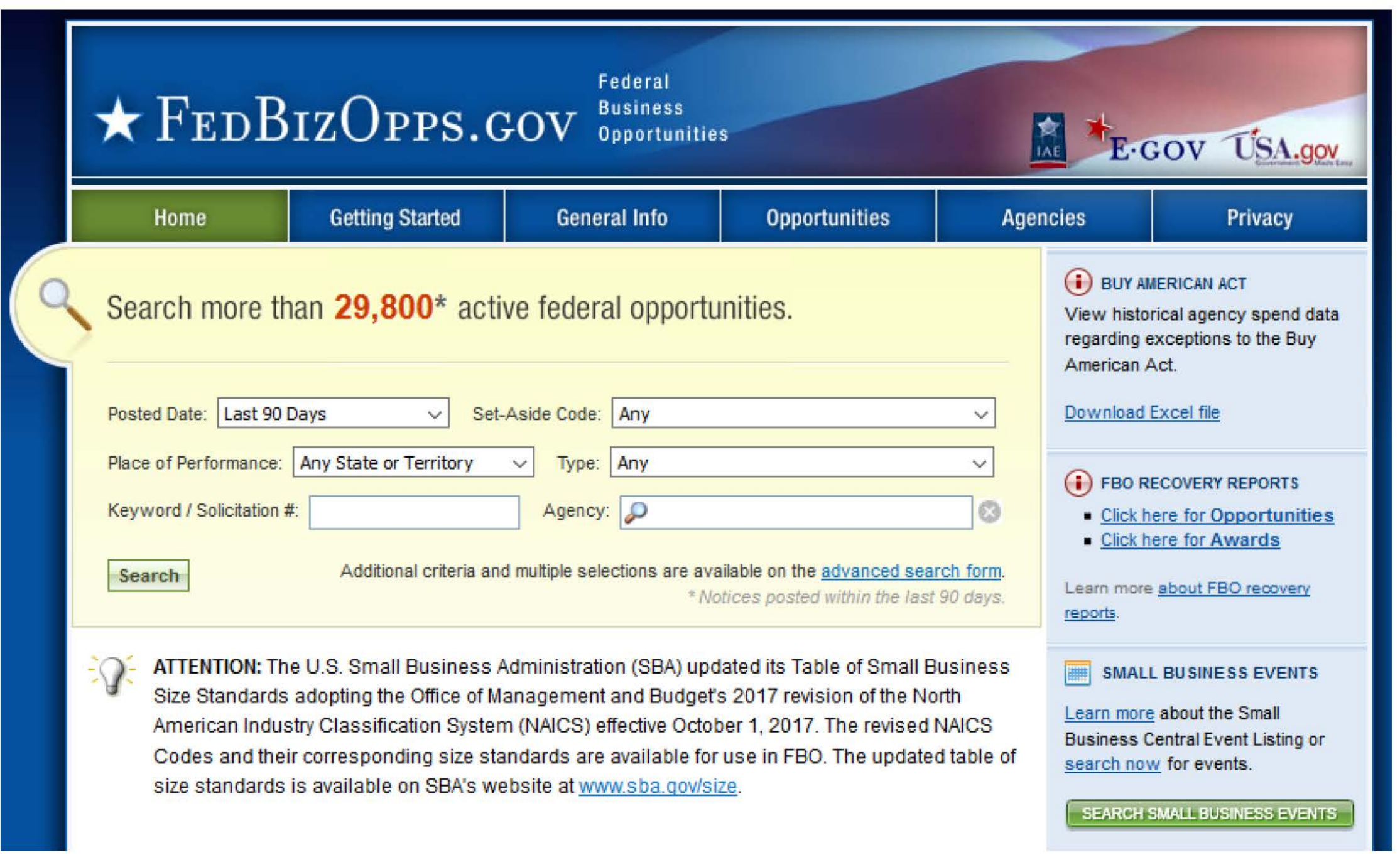




\section{www.labpartnering.org}

\section{LAB PARTNERING SERVICE}

Connecting investors with experts and resources for energy technologies.

The Lab Partnering Service is a service of the U.S. Department of Energy's (DOE) Energy Investor Center. The service provides investors, and other parties looking to advance energy innovation, a single location to connect with leading DOE national laboratory technical experts to quickly answer innovation questions, as well as discover opportunities for building partnerships. Our goal is to increase access to the information needed to make informed decisions. Leam more

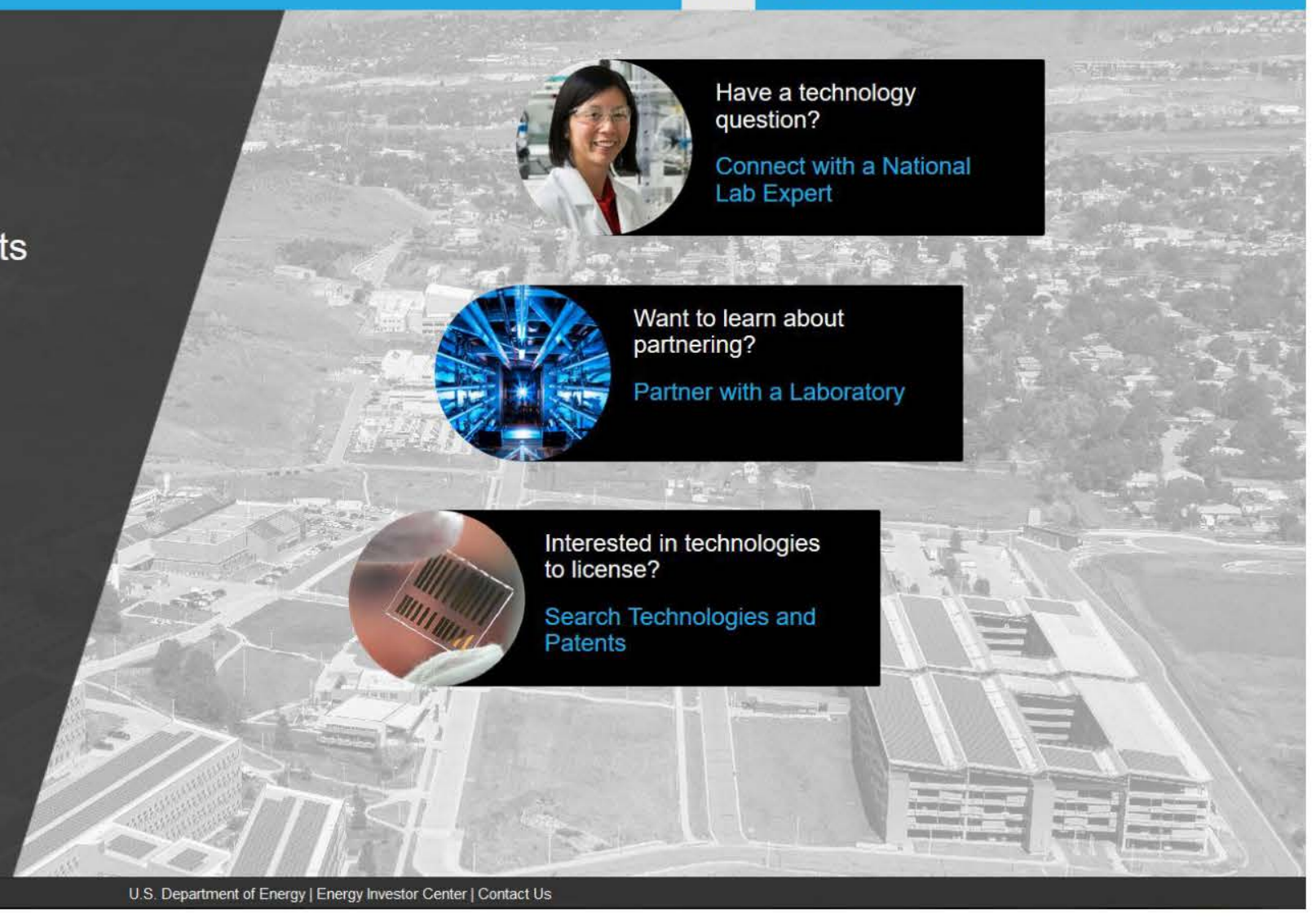

\section{䓴 Fermilab}




\section{https://vps.labworks.org}

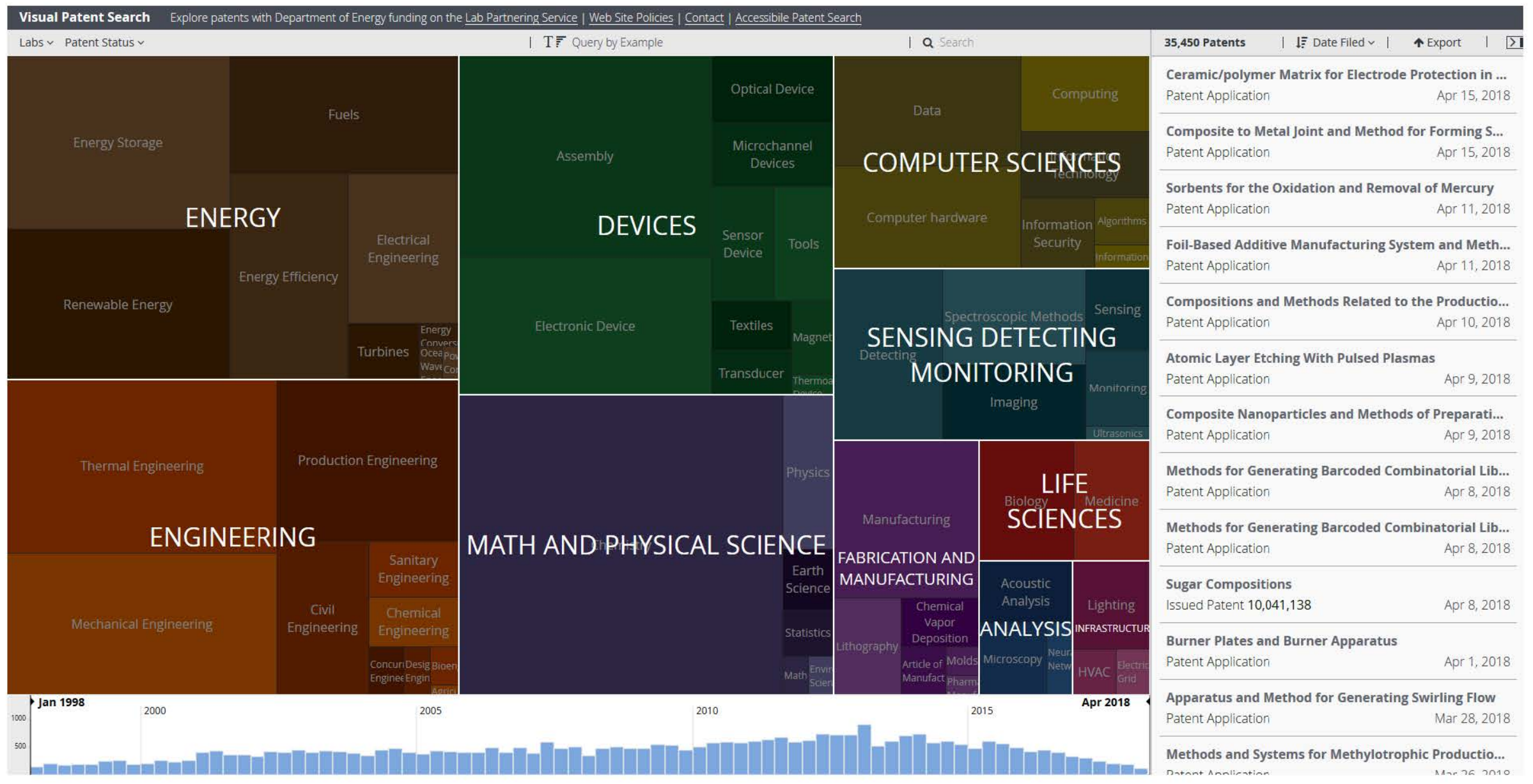




\section{Office of Partnerships \& Technology Transfer (OPTT)}

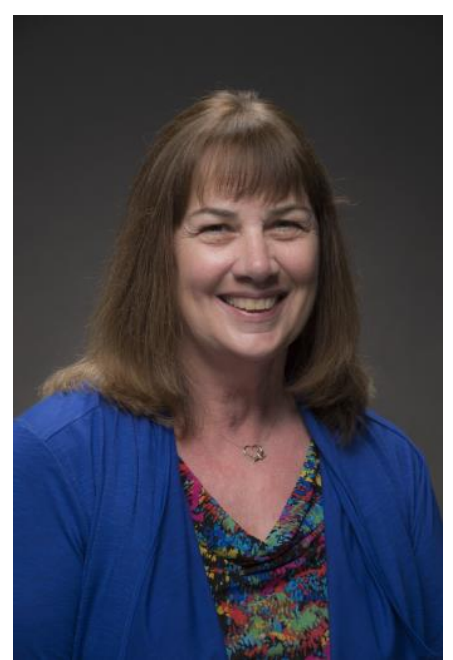

Cherri J Schmidt Manager, OPTT 630-840-5178 cherri@fnal.gov
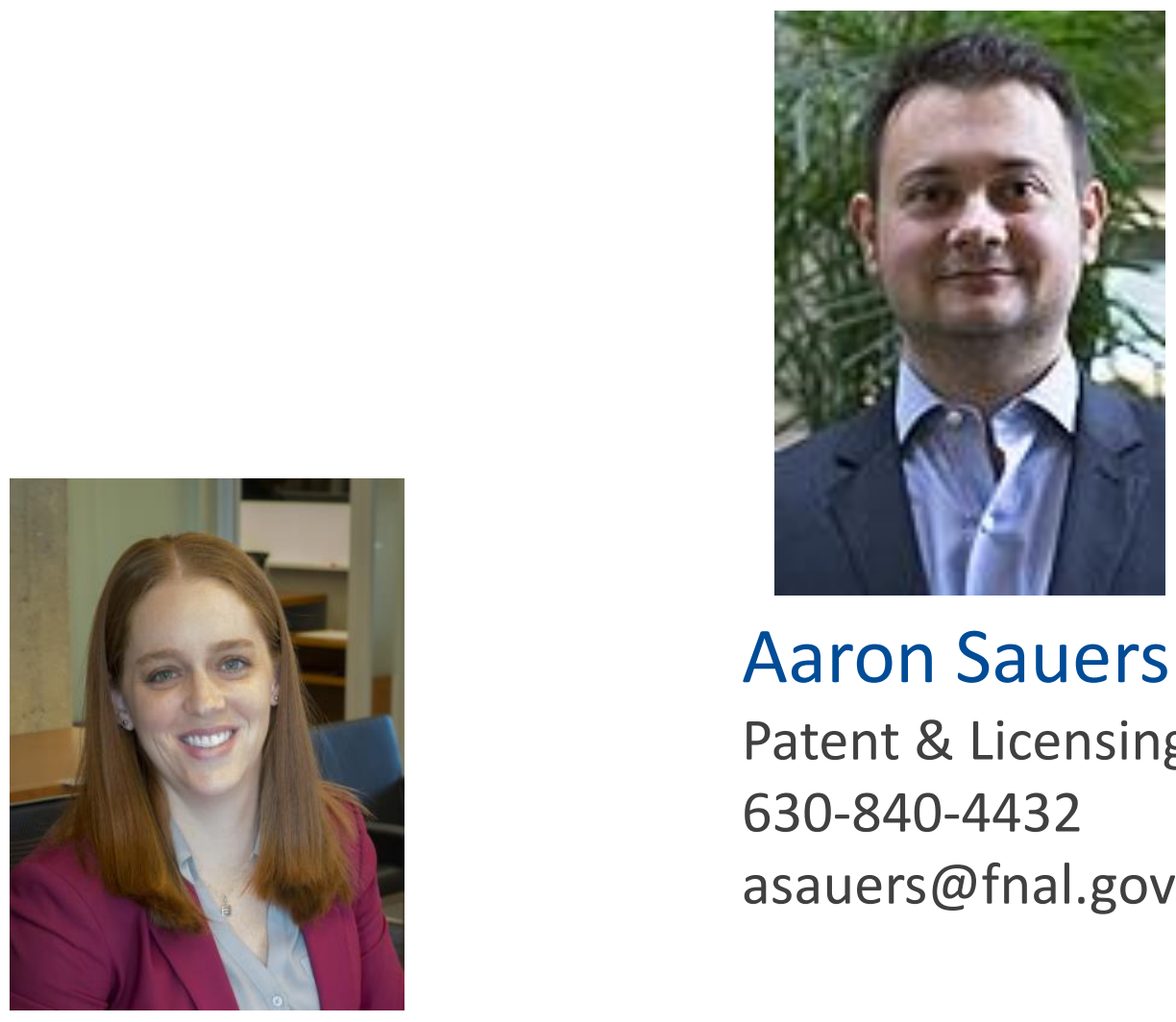

Aaron Sauers Patent \& Licensing Executive 630-840-4432 asauers@fnal.gov
Stephany Unruh

Partnership Coordinator 630-840-8424 stephany@fnal.gov 


\section{Thank you!}

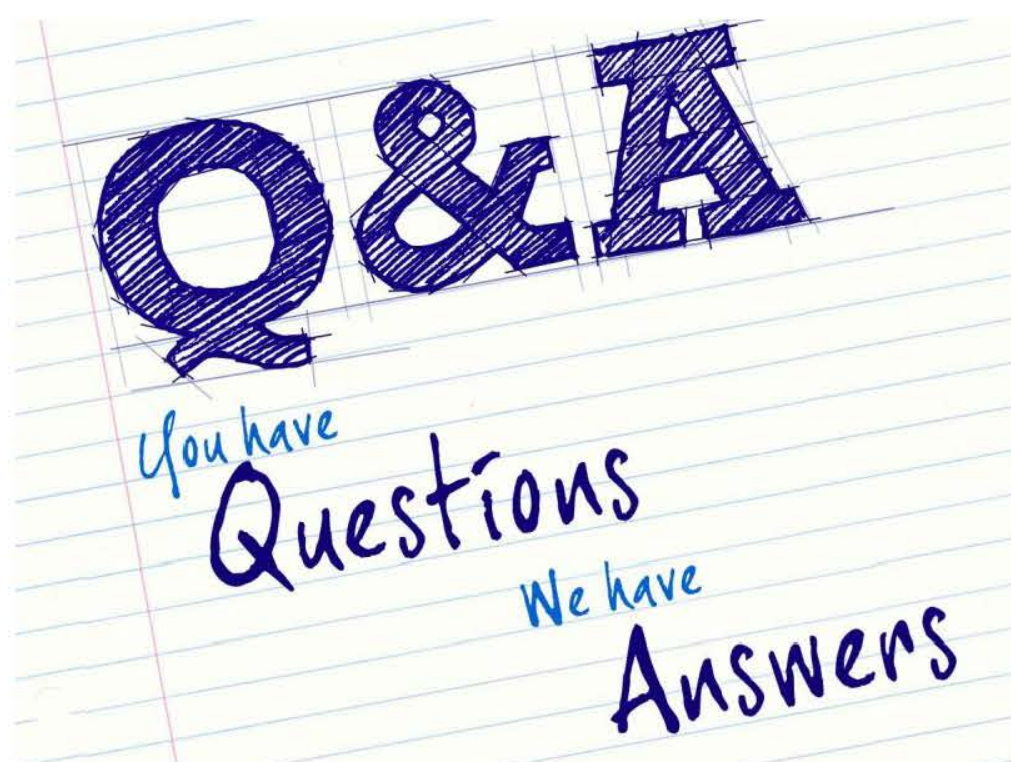




\section{Technology Transfer Mechanisms at DOE Facilities}

\begin{tabular}{|c|c|c|c|c|c|c|c|}
\hline Agreement & Use & Funding & Subject Inventions & Generated Data & U.S. Competitiveness & Cost & Highlights \\
\hline $\begin{array}{l}\text { Cooperative } \\
\text { Research and } \\
\text { Development } \\
\text { Agreement } \\
\text { (CRADA) }\end{array}$ & $\begin{array}{l}\text { Collaborative research } \\
\text { between DOE Labs and } \\
\text { public and/or private } \\
\text { entities for the mutual } \\
\text { benefit of the parties }\end{array}$ & $\begin{array}{l}\text { Private } \\
\text { and/or } \\
\text { Federal } \\
\text { funds }\end{array}$ & $\begin{array}{l}\text { Lab and Participant may } \\
\text { elect their own } \\
\text { inventions and } \\
\text { Participant has right to } \\
\text { negotiate exclusive } \\
\text { license to Lab inventions }\end{array}$ & $\begin{array}{l}\text { Protected for up } \\
\text { to } 5 \text { years }\end{array}$ & $\begin{array}{l}\text { Products embodying IP } \\
\text { resulting from CRADA shall be } \\
\text { manufactured substantially in } \\
\text { the U.S. }\end{array}$ & $\begin{array}{l}\text { Lab and } \\
\text { Participant may } \\
\text { share costs or } \\
\text { Participant pays } \\
100 \% \text { funds-in }\end{array}$ & $\begin{array}{l}\checkmark \text { Collaborative research } \\
\checkmark 5 \text { year data protection } \\
\checkmark \text { Designed for multi- } \\
\text { party collaborative } \\
\text { research }\end{array}$ \\
\hline \multirow{2}{*}{$\begin{array}{l}\text { Strategic } \\
\text { Partnership } \\
\text { Project } \\
\text { (SPP) }\end{array}$} & \multirow[t]{2}{*}{$\begin{array}{l}\text { Work for businesses } \\
\text { and other non-federal } \\
\text { entities using highly } \\
\text { specialized or unique } \\
\text { DOE facilities, services } \\
\text { or technical expertise }\end{array}$} & $\begin{array}{l}\text { Private } \\
\text { funds }\end{array}$ & $\begin{array}{l}\text { Sponsor may elect title } \\
\text { to Subject Inventions }{ }^{1}\end{array}$ & $\begin{array}{l}\text { Protected as } \\
\text { Sponsor's } \\
\text { proprietary data } \\
\text { w/limited } \\
\text { exceptions }{ }^{1,2,3}\end{array}$ & $\begin{array}{l}\text { U.5. Preference: Sponsor } \\
\text { agrees not to grant any party } \\
\text { exclusive right to use or sell } \\
\text { products embodying Subject } \\
\text { Inventions in the U.S. unless } \\
\text { products are manufactured } \\
\text { substantially in the U.S. }\end{array}$ & $\begin{array}{l}\text { Sponsor pays full } \\
\text { cost recovery }\end{array}$ & $\begin{array}{l}\checkmark \text { Sponsor typically } \\
\text { retains right to elect title } \\
\text { to subject inventions } \\
\checkmark \text { Generated data } \\
\text { treated as proprietary } \\
\checkmark \text { Option for limited Gov. } \\
\text { R\&D license }\end{array}$ \\
\hline & & $\begin{array}{l}\text { Federal } \\
\text { funds (e.g. } \\
\text { grantee) }\end{array}$ & $\begin{array}{l}\text { Lab may elect title to } \\
\text { Subject Inventions of the } \\
\text { Lab }\end{array}$ & $\begin{array}{l}\text { Unlimited Gov. } \\
\text { rights }\end{array}$ & $\begin{array}{l}\text { U.5. Preference } \\
\text { (see above) }\end{array}$ & $\begin{array}{l}\text { Sponsor pays full } \\
\text { cost recovery }\end{array}$ & $\begin{array}{l}\text { Access to unique } \\
\text { facilities and expertise } \\
\text { using federal funds }\end{array}$ \\
\hline $\begin{array}{l}\text { Agreements for } \\
\text { Commercializing } \\
\text { Technology } \\
\text { (ACT) }\end{array}$ & $\begin{array}{l}\text { Work for businesses } \\
\text { and other non-federal } \\
\text { entities using highly } \\
\text { specialized or unique } \\
\text { DOE facilities, services } \\
\text { or technical expertise }\end{array}$ & $\begin{array}{l}\text { Private } \\
\text { funds }\end{array}$ & $\begin{array}{l}\text { Initial title to the } \\
\text { designated IP Lead. (ACT } \\
\text { Participant or Lab } \\
\text { Contractor) }\end{array}$ & $\begin{array}{l}\text { Protected as } \\
\text { proprietary data } \\
\text { w/limited } \\
\text { exceptions } 1,2,5\end{array}$ & $\begin{array}{l}\text { U.5. Preference } \\
\text { (see above) }\end{array}$ & $\begin{array}{l}\text { Participant pays } \\
\text { full cost recovery } \\
\text { plus additional } \\
\text { negotiated } \\
\text { compensation to } \\
\text { the Contractor }\end{array}$ & $\begin{array}{l}\checkmark \text { Flexible terms for IP, } \\
\text { indemnity, adv. payment } \\
\checkmark \text { Optional performance } \\
\text { guarantee } \\
\checkmark \text { Negotiable IP terms } \\
\checkmark \text { Option for limited } \\
\text { Gov. R\&D license }^{3}\end{array}$ \\
\hline $\begin{array}{c}\text { Proprietary } \\
\text { User Agreement }\end{array}$ & $\begin{array}{l}\text { User may access } \\
\text { designated facilities to } \\
\text { conduct its own } \\
\text { proprietary research }\end{array}$ & $\begin{array}{l}\text { Private } \\
\text { funds }\end{array}$ & $\begin{array}{l}\text { User may elect title to its } \\
\text { Subject Inventions }\end{array}$ & $\begin{array}{l}\text { User may } \\
\text { protect as } \\
\text { proprietary }\end{array}$ & $n / a$ & $\begin{array}{l}\text { User pays } \\
\text { approved user } \\
\text { rate }\end{array}$ & $\begin{array}{l}\checkmark \text { Generated data } \\
\text { treated as proprietary } \\
\checkmark \text { Merit based access to } \\
\text { unique facilities }\end{array}$ \\
\hline $\begin{array}{l}\text { Non-Proprietary } \\
\text { User Agreement }\end{array}$ & $\begin{array}{l}\text { Non-proprietary } \\
\text { research at designated } \\
\text { facilities }\end{array}$ & $n / a$ & $\begin{array}{l}\text { Lab and User may elect } \\
\text { their own Subject } \\
\text { Inventions }\end{array}$ & $\begin{array}{l}\text { Unlimited Gov. } \\
\text { Rights }\end{array}$ & $\begin{array}{l}\text { U.5. Preference } \\
\text { (see above) }\end{array}$ & $\begin{array}{l}\text { Each party } \\
\text { covers own cost }\end{array}$ & $\begin{array}{l}\checkmark \text { Merit based access to } \\
\text { unique facilities }\end{array}$ \\
\hline
\end{tabular}

Certification: The Lab provided this DOE technology transfer matrix and explained all the options available including the availability of WFO agreements and CRADAs. The Lab has also disclosed in writing the relative cost differential between performing the proposed scope of work under ACT, a non-federal WFO agreement, and a CRADA (including any additional compensation to the Contractor under ACT).

By

Signature:
(Sponsor/Participant/User Name)

Date

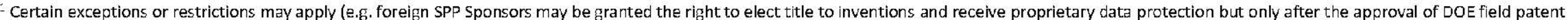

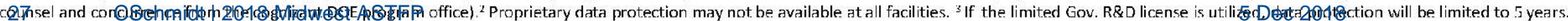

